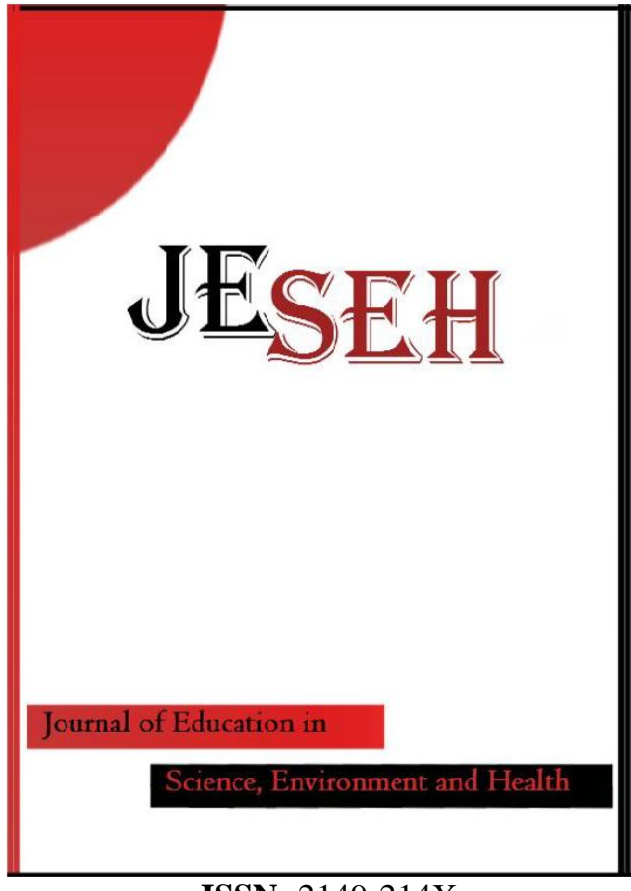

ISSN: $2149-214 \mathrm{X}$

\section{Journal of Education in Science,} Environment and Health

\author{
www.jeseh.net
}

Pre-Service Teachers' Cognitive and Metacognitive Processes in Integrated STEM Modeling Activity

\section{Mehmet Ali Kandemir ${ }^{1}$, Ilyas Karadeniz ${ }^{2}$}

${ }^{1}$ Balikesir University

${ }^{2}$ Siirt University

To cite this article:

Kandemir, M.A. \& Karadeniz, I. (2021). Pre-service teachers' cognitive and metacognitive processes in integrated STEM modeling activity. Journal of Education in Science, Environment and Health (JESEH), 7(2), 104-127. https://doi.org/10.21891/jeseh.832574

This article may be used for research, teaching, and private study purposes.

Any substantial or systematic reproduction, redistribution, reselling, loan, sub-licensing, systematic supply, or distribution in any form to anyone is expressly forbidden.

Authors alone are responsible for the contents of their articles. The journal owns the copyright of the articles.

The publisher shall not be liable for any loss, actions, claims, proceedings, demand, or costs or damages whatsoever or howsoever caused arising directly or indirectly in connection with or arising out of the use of the research material. 


\title{
Pre-Service Teachers' Cognitive and Metacognitive Processes in Integrated STEM Modeling Activity
}

\author{
Mehmet Ali Kandemir, Ilyas Karadeniz
}

\begin{tabular}{|c|c|}
\hline Article Info & Abstract \\
\hline Article History & $\begin{array}{l}\text { This study was conducted during two educational technology courses in spring } \\
\text { term of } 2016-2017 \text { academic years. The participants of the study were pre- }\end{array}$ \\
\hline $\begin{array}{l}\text { Published: } \\
01 \text { April } 2021\end{array}$ & $\begin{array}{l}\text { service teachers who were in mathematics teaching program in a university } \\
\text { located at the west part of Turkey. Pre-service teachers were asked to solve a }\end{array}$ \\
\hline $\begin{array}{l}\text { Received: } \\
05 \text { March } 2020\end{array}$ & $\begin{array}{l}\text { complex problem that requires mathematical model eliciting activities and report } \\
\text { their solution. While pre-service teachers were solving the problem and writing } \\
\text { their report, they were audio recorded. Additionally, their solutions and reports }\end{array}$ \\
\hline $\begin{array}{l}\text { Accepted: } \\
06 \text { September } 2020\end{array}$ & $\begin{array}{l}\text { for problem were collected as data sources. All three various data sources used } \\
\text { for triangulation to make the data collection process more reliable. The problem- } \\
\text { solving behavior from the study conducted by Kim et al. (2013) was used as the }\end{array}$ \\
\hline Keywords & $\begin{array}{l}\text { theoretical framework. First, the behavior is classified as cognitive or } \\
\text { metacognitive. Then the behavior (either cognitive or metacognitive) is also }\end{array}$ \\
\hline Metac & classified as at individual, social, or environmental levels. Additionally, Lesh \\
\hline $\begin{array}{l}\text { Model eliciting activity } \\
\text { Pre-service } \\
\text { teachers }\end{array}$ & $\begin{array}{l}\text { Translation Model was used to decide the representations of mathematical } \\
\text { content knowledge codes for metacognitive activities. The implications of this } \\
\text { study are the developed metacognitive activities for pre-service teachers. }\end{array}$ \\
\hline STEM & $\begin{array}{l}\text { Additionally, there is potential usage of technology for the role of metacognition } \\
\text { in mathematics education. }\end{array}$ \\
\hline
\end{tabular}

\section{Introduction}

Mathematical modeling has been increasingly viewed as an educational approach in K-16 classroom (Erbaş et al., 2014; Kaiser et al., 2011). The National Council of Teachers of Mathematics (NCTM) has identified mathematical modeling as one of major abilities in algebra standards (NCTM, 2000). All students from elementary levels to higher education are expected to elicit and use mathematical models (Butler Wolf, 2015). However, studies on a cohesive conceptualization that how mathematical modeling should be incorporated into K-16 mathematics instructions are very limited (Ang, 2015; Blum \& Ferri, 2009; Lesh \& Fennewald, 2010; Kaiser \& Sriraman, 2006).

Teachers have an important role in developing mathematical modeling abilities and competencies of students. According to Gould and Wasserman (2014), teachers need to find meaningful and effective ways to integrate mathematical modeling tasks into instruction. However, implementation of mathematical modeling in the classroom can be challenging (Niss et al., 2007). Difficulties in integrating mathematical modeling into instruction may STEM from the teachers' lack of experience with mathematical modeling (Doerr, 2007; Tam, 2011). Very few pre-service teachers in teacher education programs and in-service teachers learned how to engage students in mathematical modeling activities and prepare and implement such activities (Doerr, 2007; Tam, 2011). Successful learning of mathematical modeling depends on teachers' skills. Therefore, in-service and pre-service teachers must be equipped with knowledge and educational experiences in mathematical modeling activities (Niss et al., 2007). Niss et al. (2007, p. 20) stated that "the inclusion of modeling in teacher pre-service and in-service education courses must be effectively promoted." According to Teague, Levy and Fowler (2016), educational experiences regarding mathematical modeling (open-ended projects, collaboration, use of real data, technology, technical writing, and common mathematical content) should be included in the mathematics teaching methods courses for pre-service teachers.

There is limited evidence that methods courses can address how engaging mathematical modeling tasks lead to teaching and learning mathematics and skills; however, more research on how pre-service teachers learn mathematical modeling is needed (Blum, 2011; Cai et. al., 2014). Pre-service teachers should comprehend what mathematical modeling is, what are the aims and benefits of mathematical modeling and mathematical modeling processes. Their mathematical modeling skills and competencies should be developed with mathematical 
modeling activities integrated into methods courses (Bal \& Doganay, 2014; Lingefjärd, 2007a, 2007b; Lowery, 2002; Tan \& And, 2013).

In-service and pre-service teachers' modelling skills and competencies should be developed and improved. According to Blum (2011), metacognition is playing crucial role for developing mathematical modelling competencies. "However, despite the presumed importance of metacognition for modelling, only a few studies have been conducted for answering how metacognition influences the development of modelling competencies and the modelling process, and how to foster' metacognitive modelling competencies best" (Vorhölter, 2018, p. 343). There is a gap in the literature how pre-service mathematics teachers use cognitive and metacognitive skills in a mathematical modelling task.

This paper focuses on cognitive and metacognitive skills and levels and mathematical content knowledge of preservice mathematics teachers in a model eliciting task. For these purposes, we used two frameworks (Johnson \& Lesh, 2003; Kim et al., 2013) related to cognitive and metacognitive levels in complex problem-solving task and mathematical content knowledge in mathematical modelling. These two frameworks are Models and Modeling Perspectives (MMP; Kim et al., 2013) and Lesh Translation Model (Johnson \& Lesh, 2003) that are explained with details in the method section used for coding.

\section{Theoretical Framework}

\section{Modeling}

It is aimed to raise individuals who are able to create solutions for real world problems, to apply the learned mathematics in their life, and to be aware of the connection between mathematics and real world with mathematics education. It is suggested to bring more real-world problems in mathematics classes to get learners more interested in the mathematics (Kaiser \& Schwarz, 2006). Mathematical modelling is the process of expression, solution, and evaluation of real-world problems (Haines \& Crouch, 2007). Therefore, mathematical modelling has an important role on the solution of the real-world problems.

Modelling activities is very appropriate to apply in group settings (Doruk, 2010). Particularly, modelling can be more useful and practical in small group settings (English et al., 2005; Eric, 2010; Fox, 2006). Group members can help each other in the modelling. Therefore, group work creates a possibility for peer learning. For instance, Deniz and Akgun (2014) concluded that secondary school students found the modelling activities very interesting and more comprehensible. In addition, these students indicated that the group study was very useful, and they have positive thoughts about these kinds of activities applied in their mathematics classes (Deniz \& Akgun, 2014).

\section{Model Eliciting Activities (MEAs)}

Model eliciting activities (MEAs) are problem-solving activities that elicit a model. "These solutions require to express students' current ways of thinking in forms that are tested and refined multiple times" (Lesh \& Yoon, 2007, p. 163). The goal of MEAs is to "engage students' 'real heads' in their school activities and close the gap with their "school heads" (Lesh \& Doerr, 2003, p. 24). MEAs are designed explicitly to reveal and examine students' perceptions and prior knowledge while providing extension, revision, and integration of their ideas to develop a foundation for more abstract or formal ways of understanding (Lesh et al., 2000).

Real-world, open ended, and creative problems requiring the solvers to develop a meaningful, real life situation and create a symbolic model or tool to find a solution are used in MEAs. Problems in MEAs require students to work in collaborative teams (groups) to build and refine a mathematical model for the given a real-world context with the criteria that enables assessment leading to improved models (Diefes-Dux et al., 2008; Lesh \& Doerr, 2003; Lesh et al., 2000). There is no only one right answer for the problems in MEAs. MEAs allow divergent thinking to produce different possible models for solutions (Diefes-Dux et al., 2008; Lesh et al., 2000).

MEAs include an iterative process to improve better solutions (Rodgers et al., 2015). MEAs focus on the process rather than the product. The important artifact is the model rather than the results in MEAs (Diefes-Dux et al., 2008; Lesh \& Doerr, 2003). The process of solving MEAs reveals how students interpret a given mathematical situation. They develop understanding through mathematizing (e.g. quantifying, dimensionalizing, organizing, computing, explaning) the problem (Diefes-Dux et al., 2008; Lesh \& Doerr, 2003; Lesh et al., 
2000). Then students communicate about a model and process to address the problem (Diefes-Dux et al., 2008; Lesh \& Doerr, 2003; Lesh et al., 2000).

MEAs are characterized by the following six principles:

1. The Reality Principle: MEAs should be realistic and relevant to the students' life. This principle enables students to make sense of situation by ensuring the scenario could happen in real world, which brings the personal meaningfulness to the learning. "One way for curricula developers to test whether the reality principle is to ask, 'could this really happen in a real-life situation?"' (Lesh et al., 2000, p.597).

2. The Model Construction Principle: This principle is interconnected to guide students to create a model and incorporate the development of an explicit construction, description, explanation, or justification of a mathematical situation. The model must demonstrate students' thinking processes. According to Lesh and Doerr (2003), "MEAs are intended to be thought revealing activities" (p.452).

3. The Self-Assessment Principle: This principle requires students to share, assess and modify their models in multiple ways. Students should be assessing their models by given criteria based on improvement on their models. The activity promotes self-assessment on part of students (Carlson et al., 2003, p.472; Lesh et al., 2000).

4. The Construct Documentation Principle: This principle encourages self-reflection on the part of student and emphasizes researchers' investigation into their understanding. Students are also required to document their solutions and thoughts in written or oral form. "One way to make it natural for students to externalize their ways of thinking is to have them work in groups where such processes as planning, monitoring, and assessing must be carried out explicitly" (Lesh et al., 2000, p.623).

5. The Simple (Effective) Prototype Principle: This principle ensures that the context is memorable and requires the development of a significant construct. The principle asks the question "is the situation as simple as possible, while still creating the need for a significant model?" (Lesh et al. 1997, p.3).

6. The Model (Construct) Generalization Principle: This principle expresses that students' models should work with other data sets and have the potential for modification of similar situations. The models that students create must be able to be shared, modified and used beyond immediate problem situation (Lesh et al., 2000). The principle asks the question "does the model provide a general model for analyzing this type of dynamic situation?” (Carlson et al., 2003, p. 472).

Problems in MEAs are intrinsically designed to explore social experiences in small group work (English et al., 2005). Therefore, social interactions are highly important for MEAs. Constructivist learning theory argues that students build knowledge upon their previous knowledge via their experiences and social interactions (Duffy \& Cunningham, 1996; Ferguson, 2007). MEAs enable an open-ended learning environment. Therefore, they support development of mathematical skills and divergent thinking (Diefes-Dux \& Imbrie, 2008). MEAs can be seen as a part of cooperative learning pedagogy because they provide students to gain personal experiences with model development. MEAs also enable students to identify aspects of high-quality models and gain modeling abilities (Lesh \& Doerr, 2003; Zawojewski et al., 2008).

\section{Lesh Translation Model with Technology based Representational Media Layer}

Bruner identified cognitive representation had three modes: Enactive, iconic and symbolic (Bruner, 1964). Enactive Representation is defined as the representation that an individual understands through motor responses. Iconic Representation is defined as the representation that an individual uses images to represent understanding. Symbolic Representation is defined as the representation that an individual uses symbol systems such as language, musical notation, and mathematical notation to represent understanding (Driscoll 2000, p. 225). The learner moves from physically modeling the problem with materials (enactive) to diagramming or graphing (iconic), and to put the problem into an abstract mathematical form (symbolic; Lapp \& Cyrus, 2000, p.507). At the end of 1970s, Lesh adapted Bruner's framework by separeting the iconic mode into manipulatives and pictures and the symbolic mode into spoken verbal symbols and written symbols. Thus, Lesh has constructed his translation model. Mathematical ideas can be expressed in five different modes based on the Lesh Translation Model (Figure 1). These modes are manipulatives, pictures, real life situations, spoken language, and written symbols. These modes work interactively rather than in a linear relationship (Clement, 2004; Cramer,2003; Lesh, 1979; Lesh et al., 1987; Post et al., 1986; Post \& Cramer, 1989).

The Lesh Translation Model is a measure of how strong the content knowledge of students is through five main representations and translations between and within these representations: (1) Representation through realistic, 
real-world, or experienced contexts (based on metaphors), (2) symbolic representation, (3) language (verbal symbols) representation that includes mathematics vocabulary, (4) pictorial (diagram) representation that are static figurative models, and (5) representation with manipulatives (concrete, hands-on models) such as Lego blocks, number lines, fraction bars, and tangram in which the relationships and operations built into the system that fits many everyday situations (Lesh \& Doerr, 2003).

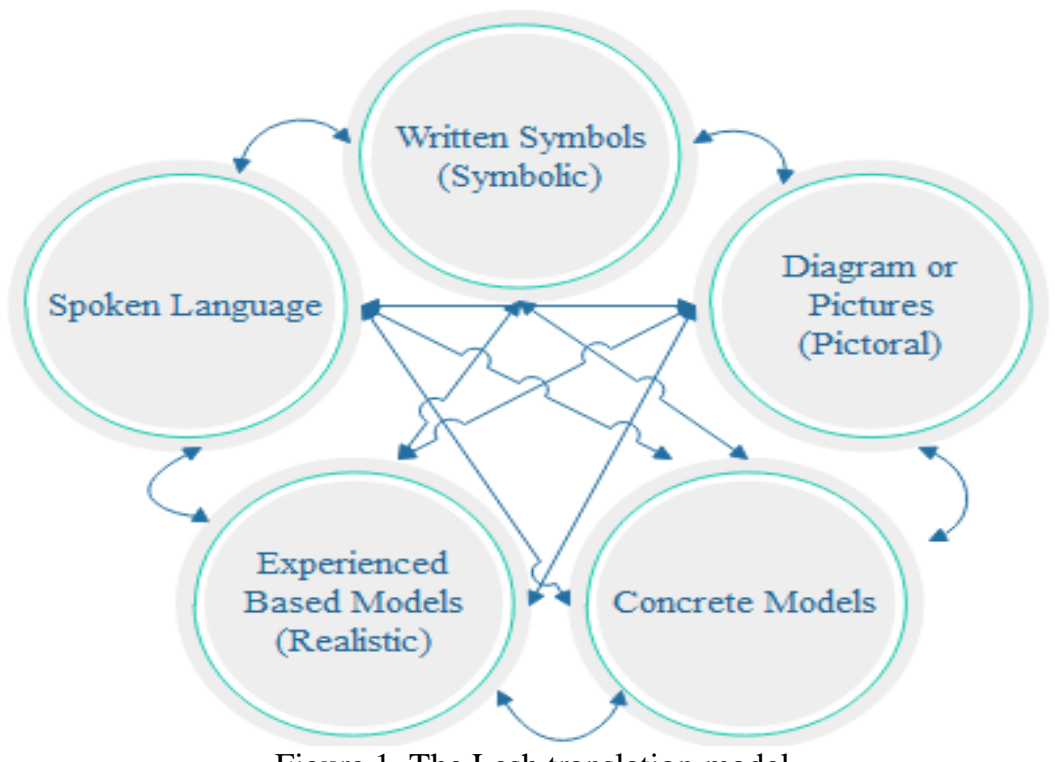

Figure 1. The Lesh translation model

The Lesh translation model asserts that the understanding of concepts lies in the skills of learners to represent mathematical concepts through five different sets of representation and to translate within and between multiple modes of representation (Cramer, 2003; Lesh \& Doerr, 2003). A translation in this model is the reinterpretation of a mathematical concept within the same representation or between different representations (Cramer et al., 2009). It is important that students learn mathematics through representations. Conceptual understanding can be developed when students translate between representations (NCTM, 2000). Mathematical representations and communication for the deep understanding of mathematical concepts are centered in the Lesh Translation Model (Moore et al., 2013). Therefore, the model encouraged students to work together as a team and focus on communication and metacognition skills (Glancy \& Moore, 2013).

Tables, equations, and graphs were added to Lesh's translation model by some researchers. Lesh and Doerr (2003) described a translation model with eight modes. The model with eight modes serves a variety of representational media. Representational media, such as graphs, tables, and equations represent innovative curriculum materials in the high school and college (Lesh \& Doerr, 2003).

Jonhson and Lesh (2003) improved the previous model with eight modes of representational media by including an additional layer (figure 2) that is technology-based electronic media, called eMedia, such as computer-based animations, graphics or simulations. eMedia is dynamic, interactive, and linked. Graphing calculators and computer software can be used for eMedia layer (Johnson \& Lesh, 2003). In this study we have used GeoGebra as a computer software for eMedia layer. The Lesh Translation Model with technology-based representational media layer is used to measure pre-service teachers' mathematical content knowledge.

Lesh Translation Model was also used as a theoretical framework in this study. This model has five categories for representation (see Figure 1 and 2). These are realistic, pictorial, language, symbolic, and concrete. Representations related to real world are in realistic group. All representations with pictures are in pictorial group. Language group includes the words used by participants to describe the representations. When the participants use an equation, calculation or table, these are in the symbolic group. Using body part, meter, ruler or any measurement or solid materials are in the concrete group (Lesh et al., 2003; Stohlmann et al., 2013).

The Lesh Translation Model includes the representations of mathematical content knowledge. Hence, MEAs are typically organized including and/or asking to develop multiple representations. The Lesh Translation Model has an important adaptation to the idea of MEAs. Therefore, the Lesh Translation Model was also used to analyze pre-service teachers' explanations for the solution of footprint problem in this study. 


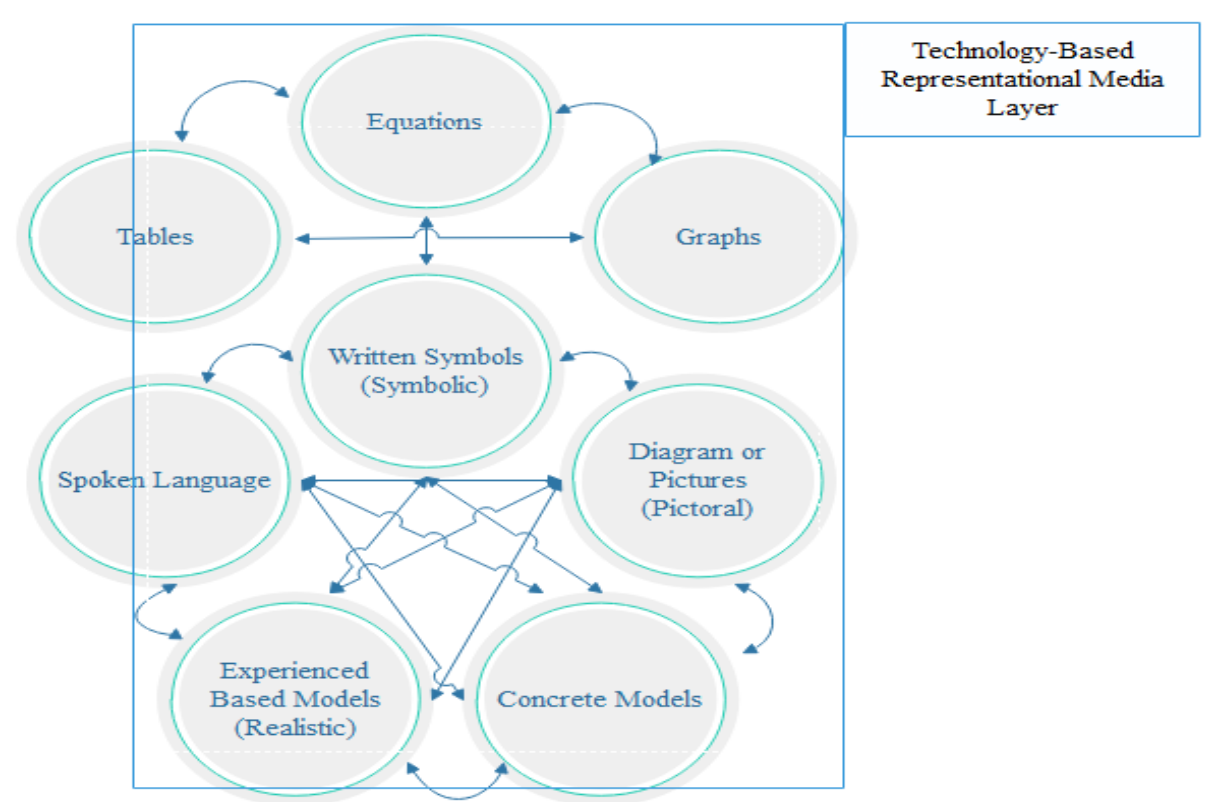

Figure 2. Lesh translation model with technology-based representational media layer

\section{Cognition and Metacognition in MEAs and Problem Solving}

Cognitive and metacognitive thinking processes are involved in problem solving and MEAs (Chan, 2008; Lamon, 2003; Lesh \& Zawojewski, 2007; Lester et al., 1989; Magiera \& Zawojewski, 2011). Cognition is a mental process of receiving knowledge, understanding, problem solving, learning, thinking, knowing, memorizing, judging, and reasoning (Dunlosky \& Metcalfe, 2009; Revlin, 2013).

Problem solving process needs cognition and metacognition thoughts (Artzt \& Armour-Thomas, 1992; Lester et al., 1989). During problem solving process, cognition and metacognition are parallel and interactive rather than sequential (Mayer, 1998; Schoenfeld, 1992). Problem solving competencies and mathematical cognition can be observed through MEAs (Lester \& Kehle, 2002; Lesh \& Lehrer, 2003). MEAs are intertwined with problem solving and cognition (Goldin, 2007; Roth, 2007). Problem solving involves iterative modeling cycle. For the reason of MEAs are challenging, authentic and realistic, learners may not have an immediate solution for the given problem (Chan, 2008). MEAs can be so difficult for students because MEAs have cognitive and metacognitive demands (Blum \& Leiss, 2007).

Metacognition has been explained as the development of students' outcomes (Biggs, 1987; Brown \& De Loache, 1983). Some researchers have explained metacognition in mathematics education as successful mathematical performance (Goos, 1994; Stacey, 1991). Problem solving is a significant skill for mathematical success. Problem solving has been seen by some educators as a higher cognitive activity and it involves cognitive processes (Gagne \& Medsker, 1996; Mayer, 2003; Polya, 1957). Problem solving also includes monitoring and reflecting processes that are components of metacognition (NCTM, 2000). As a result, problem solving has been seen as a complex process with interplay cognition and metacognition by some educators (Artzt \& Armour- Thomas, 1992; Lester et al., 1989; Schoenfeld, 1992).

Metacognition has an effect on both problem solving and mathematics success (De Corte et al., 1996; Lester, 1994; Lucangeli \& Cornoldi, 1997; Kramarski et al.2002; Pintrich et al., 1994; Trainin \& Swanson, 2005). Cardelle-Elewar (1992) demonstrated that students who have faced difficulties in mathematics did not use metacognition strategies. Metacognition helps students to overcome obstacles and difficulties in the process of mathematical problem-solving (Goos, 2002; Pugalee, 2001; Rysz 2004; Schoenfeld 1992; Stillman \& Galbraith, 1998; Yimer \& Ellerton 2006).

An aim of mathematics education is to develop modeling competencies. Metacognition has an important role in mathematical modeling activities and competencies (Blum, 2011; Maßß, 2007). Although knowledge and skills are very important for problem solving and metacognitive strategies, they are not sufficient. Stillman (2004) identified cognitive and metacognitive strategies in applications tasks by using cognitive-metacognitive framework when students work on these tasks. There have been few studies that aimed to analyze students' 
metacognitive knowledge and strategies related to modeling problems when students work on these modeling problems (Hıdıroğlu \& Bukova-Güzel, 2015, 2016; Kim et al., 2013; Maaß, 2007; Stillman, 2011; Stillman \& Galbraith, 1998). Most studies focus on metacognitive behaviors of middle and high school students to analyze qualitative metacognitive aspects that were used in problem solving process (Artzt \& Armour-Thomas, 1992; Goos, 2002; Goos \& Galbraith, 1996; Goos et al., 2002; Jacobse \& Harskamp, 2009, 2012; Montague \& Bos, 1990; Özsoy \& Ataman, 2009; Pugalee, 2001; Teong, 2003).

Even though metacognition is thinking about one's own thinking (Stillman \& Mevarach, 2010), it should be evaluated not only at the individual level, but also at the social and environmental level (Kim et al., 2013). In general, modeling tasks are done in the group settings. Group work also requires joint planning process (Vorhölter, 2018). Student-student interaction in a small group promote metacognition to get the better solution for the problem. The correct solution for the problem can be found, if students share metacognitive roles that needed in the problem solving process (Artzt \& Armour-Thomas, 1992; Goos \& Galbraith, 1996). At the level of verbalization in modeling activity,

most acts can clearly be distinguished as metacognitive or cognitive strategies. Those used for planning together, monitoring and explaining to each other, are of a metacognitive nature, as they aim at monitoring progress; whereas making progress would be an indicator of cognitive strategy use (Vorhölter, 2018, p.346).

Therefore, we should consider social metacognition in the problem-solving process and modeling activities.

Cognition at Individual Level: At this level, the participants might think with cognitive component. There is no evaluation. Participants also do the thinking processes themselves (Kim et al., 2013).

Cognition at Social Level: At this level, the participants might think with cognitive component. There is no evaluation. And the participants do the thinking processes with others or affected by others (Kim et al., 2013).

Cognition at Environmental Level: At this level, the participants might think with cognitive component. There is no evaluation. And the participants do the thinking processes due to a learning environment (Kim et al., 2013).

Metacognition at Individual Level: At this level, the participants might think about a cognitive or metacognitive component with evaluation. And the participants do the thinking processes themselves (Kim et al., 2013).

Metacognition at Social Level: At this level, the participants might think about a cognitive or metacognitive component with evaluation. And the participants do the thinking processes with others or affected by others (Kim et al., 2013).

Metacognition at Environmental Level: At this level, the participants might think about a cognitive or metacognitive component with evaluation. And the participants do the thinking processes due to a learning environment (Kim et al., 2013).

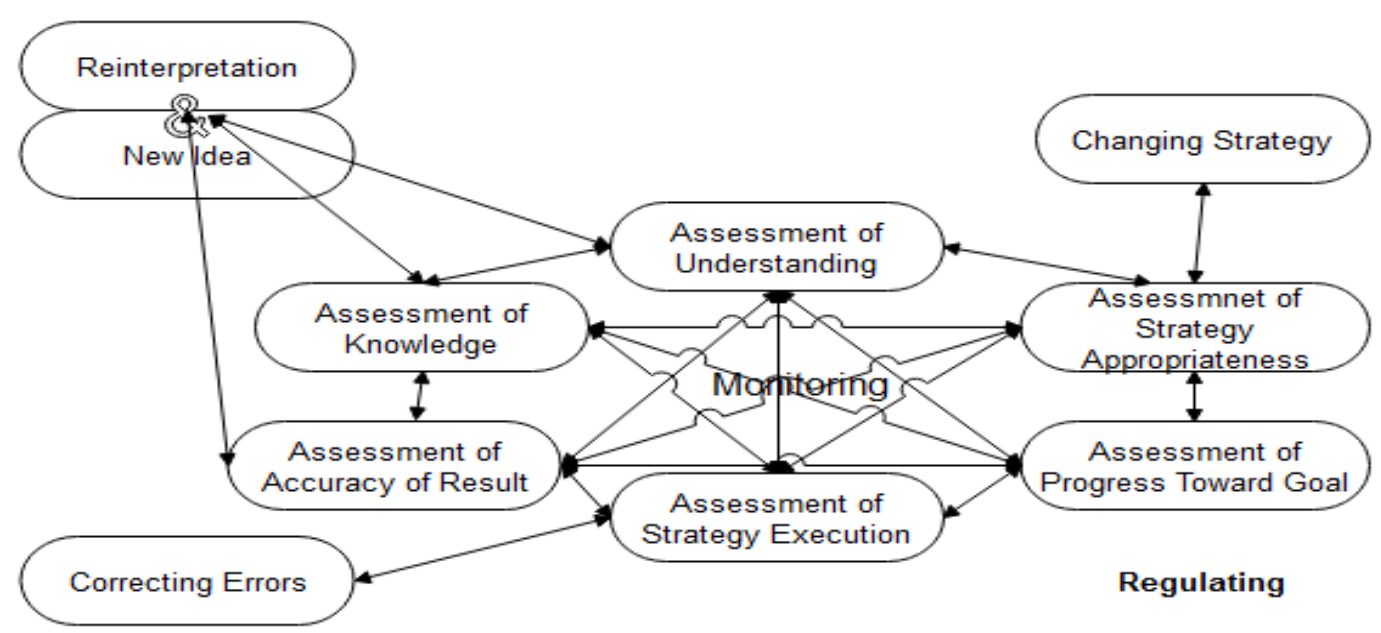

Figure 3. Models and Modeling Perspectives (MMP) view of metacognitive activities during problem solving (Kim et al., 2013). 
In this study, the framework developed by Kim et al. (2013) as nonlinear model in Figure 3 was used. The metacognitive strategy that is under monitoring or regulating activity was not investigated in this study. Therefore, changing strategies and correcting errors were removed, which are directly related to the codes assessment of strategy appropriateness and assessment of strategy execution respectively. In addition, only the code of new idea was used even there is a reinterpretation; hence, these two codes are together in the framework.

For this study, pre-service teachers' discussions for solutions of the footprint problem were analyzed based on their strategies related to cognition and metacognition levels (Kim et al., 2013) and the Lesh Translation Model (Lesh et al., 2003; Stohlmann et al., 2013). The problem solving behavior is used as a theoretical framework from the study first developed by Goos (2002) as a linear model and then improved by Kim et al. (2013) as a nonlinear model. This framework has six categories. First, the behavior is classified as cognitive or metacognitive. Then the behavior (either cognitive or metacognitive) is also classified as at individual, social, or environmental level.

\section{Integrated STEM Modeling Activity}

Today, most schools' goal is to improve students' knowledge and skills in science, technology, engineering and mathematics (STEM) fields. For students using high-technological products in present and future, they must have knowledge and skills of STEM fields. Highly qualified scientists, technologists, engineers and mathematicians have a crucial role for securing economic prosperity (Bell, 2016). Students can be better problem solvers, innovators, and logical thinkers by taking STEM courses during their educational experiences (Morrison, 2006). STEM courses also help students improve their learning skills (Dewaters \& Powers, 2006). STEM education can eliminate abstractness of mathematics and science. It also provides real-world applications related to the concepts of technology and engineering (Nugent et al., 2010).

Mathematical modeling activities and practices can be a bridge between the STEM fields (Lehrer \& Schauble, 2000). They are also more appropriate and easier to apply within existing curricula (Moore \& Smith, 2014). Model eliciting activities (MEAs) is one application of the mathematical modeling activities. MEAs can be a good example of curriculum materials for integrated STEM education (Kertil \& Gurel, 2016; Roehrig et al., 2012). Integrated STEM modeling activity can be defined as involved MEAs in all STEM related situations.

There are few studies related to integrated STEM modeling activity (Moore \& Smith, 2014; Stohlmann et al., 2013). Additionally, STEM integration often less included in undergraduate STEM education than K-12 (Moore $\&$ Smith, 2014). In terms of the contribution of this study to the literature, it is a good opportunity to investigate pre-service teachers' applications of STEM modeling activity in group settings.

\section{GeoGebra as a cognitive-metacognitive tool in integrated STEM modeling activity}

Today technology has an important role in teaching and learning mathematics. It is also getting widely influential in mathematics education (Kaput et al., 2007). Most mathematics educators explained the mathematics classroom as an environment where students are actively constructing their own understanding of mathematical ideas by using the emerging technological tools (Furner \& Marines, 2012). NCTM defined the use of technology as one of the principles of learning and teaching in mathematics education (NCTM, 2000). NCTM asserted that learners can work at higher levels of generalizations, model and solve complex and nonroutine problems, focus on decision-making and mathematical reasoning through using technological tools in mathematics classrooms (NCTM, 2000).

Computer Algebra Systems (CAS) such as Derive, Mathematica and Dynamic Geometry Software (DGS) such as Cabri Geometry and GeoGebra are powerful technological tools for teaching and learning mathematics (Hohenwarter et al., 2008). This digital software can be used as learning tools to answer problems, to communicate, or to prepare teaching materials (Borba \& Villarreal, 2005).

Technology has a significant role on mathematical modeling because of the opportunities it brings. For example, students can be more creative, and they can bring different strategies for solution by using technology (Hıdıroğlu \& Bukova-Güzel, 2014; Lingefjärd, 2000). GeoGebra is one of the most commonly used software in mathematics education nowadays. GeoGebra is multi-platform, open-source dynamic mathematics software for all levels of education that joins algebra, geometry, statistics, calculus, graphing, and tables with an easy-to-use 
package (Hohenwarter et al., 2008). Multiple representation (numeric, graphic and table) is one of the most important features of the GeoGebra. GeoGebra allows learners to construct interactive representations of points, lines, and shapes. Therefore, students are able to see the relationships between different representations easily through GeoGebra. Learners can see that a concept play different roles in mathematical situations with understanding of different representations (Herceg \& Herceg, 2007 as cited in Milanović et al., 2012; Yu \& Tawfeeq, 2011).

In model eliciting activities related to STEM education, GeoGebra enables multiple representations about a problem situation. Learners can understand the task better, associate between multiple representations, explore new knowledge and relationships, and model mathematical equations for solving a task by using GeoGebra. Learners may explain their thoughts with the help of GeoGebra. From metacognitive point of view, GeoGebra may have a stimulating role. As explained in the previous chapters of this study, the metacognition has three levels which are individual, social and environmental. Geogebra can be a useful tool in terms of environmental level of metacognition with the opportunities it brings.

\section{Integrated STEM Modelling Activity: Footprint Problem}

Footprint or Bigfoot problem (Koellner-Clark \& Lesh, 2003) (See Appendix A) was used in previous studies to investigate students reasoning skills in the concepts related to proportionality (Lesh \& Doerr, 2003; Lesh \& Harel, 2003; Stohlmann et al., 2013). This footprint problem has connections with Science, Technology, Engineering and Mathematics (STEM). For instance, the problem includes observation and measurement that are related to Science. Pre-service teachers' access and use GeoGebra covers the technology part. There are many mathematical concepts (ratios, proportions, line of best fit, scatter plots, etc.) and engineering design process that pre-service teachers work within the problem (Stohlmann et al., 2013). This problem is also motivating for pre-service teachers to solve it (Brophy et al., 2008). In addition, student-centered approach might be used via footprint problem. Therefore, students can build on their prior knowledge by bringing their own strategies for the solution of the problem (Stohlmann et al., 2013).

\section{Method}

\section{Sample}

This study was conducted in a university located in the west part of Turkey. The participants of the study were pre-service teachers who were seniors in mathematics teaching program. There were 32 pre-service teachers who were in mathematics teaching program for middle schools and 20 pre-service teachers who were in mathematics teaching program for high schools.

Participated pre-service teachers had already taken mathematics content courses (e.g., Calculus I, II) and mathematics method courses (e.g., Instructional Technology and Material Design). In the educational technology courses, pre-service teachers have learned about mathematics software such as GeoGebra and Turtle. Therefore, they already had experience with GeoGebra software. They also had experience of mathematical modeling in groups and writing report of the modelling process.

\section{Data Collection}

The data is collected in a mathematics method course named Special Teaching Methods in the 2016-2017 school years. For this study, the instructor asked pre-service teachers to solve a complex problem that requires mathematical modelling and report their solution. The instructor mentioned the mathematical modelling to warm up the pre-service teachers for the complex problem. He explained the details of this problem. The problem is called footprint problem that requires a modelling to figure out how tall a person whose footprint is given might be (See Appendix A).

Pre-service teachers were in the groups of four or six to study for the solution of the footprint problem. While pre-service teachers were solving the problem and writing their report in 4-hour course time period, they were audio recorded. Pre-service teachers were allowed to use GeoGebra software to solve the problem and they had access to GeoGebra in the Computer Lab during the course. Their solutions in GeoGebra were also collected for 
this study. Additionally, their reports for the footprint problem were collected for the study. All three data sources made the data collection process more reliable.

\section{Data Analysis}

There were two groups selected to analyze the discussion and solutions for the mathematical modeling process. Both group members were four female pre-service teachers. One group was from mathematics teaching program for middle schools and other group was from mathematics teaching program for high schools. These two groups were selected because the Grade Point Average (GPA) of these pre-service teachers' was higher than the average of their classmates in these groups. They also had adequate Pedagogical Content Knowledge (PCK) and Technological Pedagogical Content Knowledge (TPACK).

Pre-service teachers' explanations were coded based on the cognitive or metacognitive thinking. If the explanation is in the category of metacognitive thinking, then this explanation was coded such as Assessment of progress toward goal. Later, the level of this explanation (Individual, Social or Environmental) was coded (Kim et al., 2013). In the last phase, the type of representation was coded such as Language or Pictural (Johnson \& Lesh, 2003). A pre-service teacher's explanation might have more than one code based on its context. However, a pre-service teacher's explanation might not have any code because of its context. Two researchers coded the data separately at first and later the common coding was decided in agreement.

\section{Results}

In this part, findings for both groups in terms of their cognitive and metacognitive thinking and representation of mathematical content knowledge were demonstrated via graphics. In the following figures, G1 represents the four pre-service teachers (P1, P2, P3, P4) for middle school and G2 represents the four pre-service teachers (P5, P6, P7, P8) for high school. Figure 4 demonstrates how frequently the groups used cognitive and metacognitive thinking.

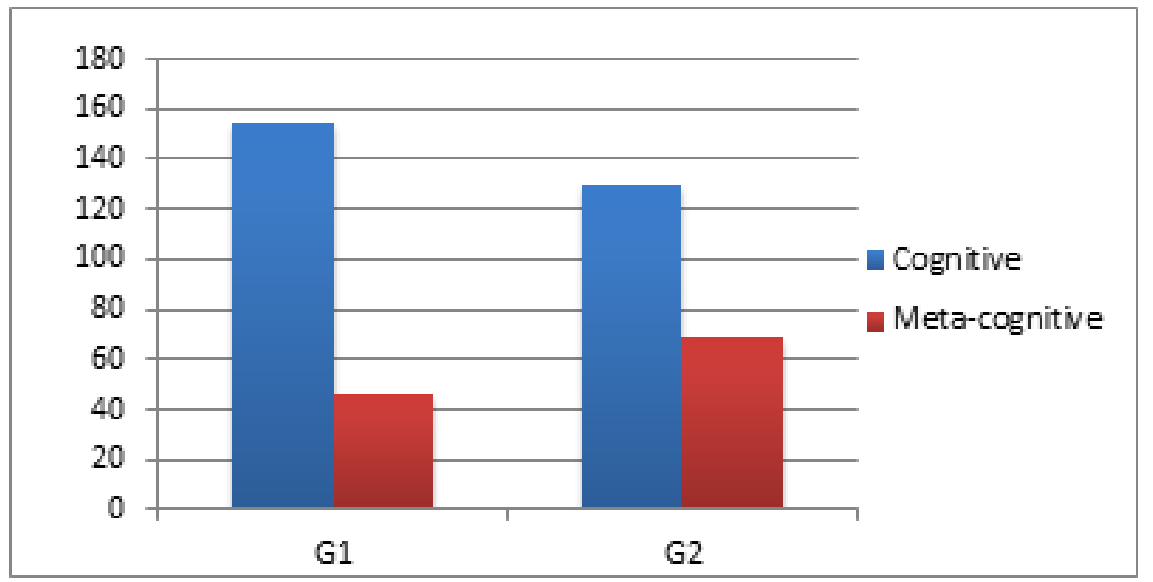

Figure 4. Pre-service mathematics teachers' statements during MEA in terms of cognitive and metacognitive expression.

The results in Figure 4 demonstrates that pre-service teachers (P5, P6, P7, P8) for high school used metacognitive thinking more than pre-service teachers (P1, P2, P3, P4) for middle school. Content and diversity of the courses they take can be the reason of the difference between high school and middle school pre-service teachers' cognitive and metacognitive expressions. High school pre-service teachers' university entry scores are generally higher in order to get into this program and the major area courses they take are more abstract and have high-level mathematics content than the courses pre-service teachers for middle school take. These can be the reasons for high school pre-service teachers' metacognitive thinking usage frequency.

Figure 5 demonstrates high school pre-service teacher group members' cognitive and metacognitive thinking individually. P7 and P8 have more cognitive and metacognitive statements than the other two pre-service teachers. In this group P5 and P7's GPAs are close to each other's GPA and higher than P6 and P8's GPAs. Therefore, it can be said that pre-service mathematics teachers' GPAs cannot be related to their metacognitive 
thinking skills. There might be other reasons for the frequency of metacognitive statements such as social interaction and technology skills.

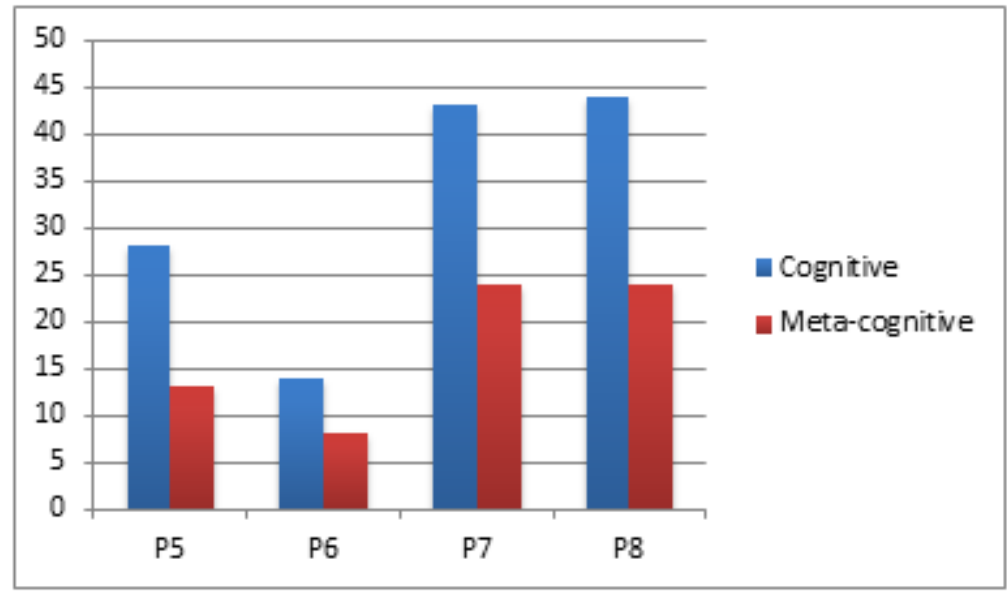

Figure 5. High school pre-service mathematics teachers' cognitive and metacognitive thinking.

Figure 6 also demonstrates middle school pre-service teacher group members' cognitive and metacognitive thinking individually.

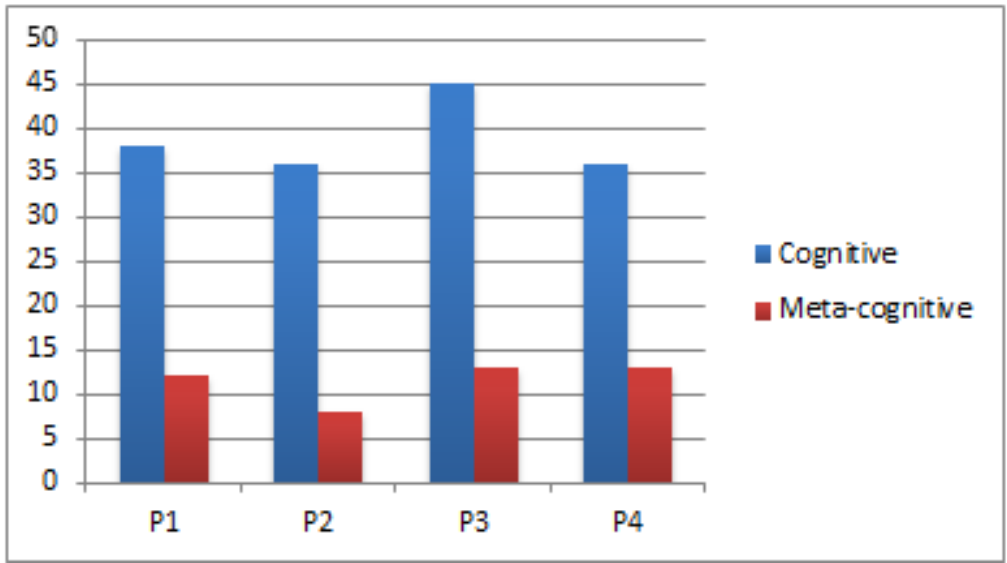

Figure 6. Middle school pre-service mathematics teachers' cognitive and metacognitive thinking.

Middle school pre-service teachers used more cognitive statements than high school pre-service teachers. P1, P2, P3 and P4's frequencies of metacognitive thinking were close to each other. All these pre-service teachers' GPAs were higher than their classmates.

The following statements were made by pre-service teachers who were participants of this study when they were solving footprint problem and writing a report for their solutions. First, the statements were translated to English. Then, they were coded by researchers. In the following sample statements, we used letter S for statement and letter P for pre-service teachers. The codes assigned by researchers are showed bold in brackets.

S1. P8: First of all, we should measure one of our feet length to figure out footprint. We should figure out the foot size based on the length. There should probably be height interval based on the foot size. Based on this, we can figure out height interval. It is not possible to decide on an absolute value (Metacognitive, New idea \& Assessment of knowledge, Individual \& Environmental level, Realistic).

S2. P5: I agree with P8. If we do that, we can find the proximate exponential function from the bivariate regression analysis in GeoGebra. We can try to figure out footprint with this function (Metacognitive, New idea \& Assessment of strategy appropriateness, Individual \& Social level, Realistic \& Language).

S3. P7: We can find the ratio with that and check if there is a ratio in our body. I mean relationship with golden ratio (Metacognitive, New idea, Individual \& Social level, Realistic \& Language). 
S4. P8: Let's say the foot size 38 is not an absolute length. It is a foot length interval (Metacognitive, New idea \& Assessment of knowledge, Individual level, Realistic).

S8. P5: First, let's measure our feet length and write down our heights (Metacognitive, Assessment of progress toward goal, Individual \& Social level, Realistic \& Language).

S18. P7: They use half integers for foot size in United Kingdom. Are they exactly for the foot length? I have measured from toe to the heel (Metacognitive, Assessment of knowledge, Individual level, Realistic \& Language).

S26 P6: Shoe template can be changed then (Metacognitive, Assessment of knowledge, Individual level, Realistic \& Language).

Pre-service teachers read the problem and then discussed the possible solutions of the problem before they spent enough time to analyze the problem. Pre-service teachers used their mathematical content knowledge to convert the real model to mathematical model. The content knowledge they used were related to the concepts of regression analysis and golden ratio of two numbers. Hence, pre-service teachers already knew how to do regression analysis in GeoGebra, they focused on the relationship between the shoe length and their heights. They also thought that this relationship happens in a standardized interval. First, they measured their feet length and heights by using their knowledge about measurement. They used metacognitive strategies effectively during this measurement step. Pre-service teachers re-considered the knowledge and produced new solutions as parts of metacognitive strategies. Therefore, they used their previous mathematical knowledge here and realistic components existed frequently.

S44. P7: One of you collect the others' data (P7 is doing herself) (Metacognitive, Assessment of progress toward goal, Individual level, Language)

S46. P7: Let's measure someone who is tall (Metacognitive, New idea, Individual level, Language).

S50. P8: But I think, there is much change... (Metacognitive, Assessment of strategy appropriateness, Individual level, Language).

S59. P5: Because there is space here (pointing the front of the shoe) (Metacognitive, Assessment of knowledge, Environmental level, Realistic \& Language)

S60. P8: Uhmm...

S61. P5: My foot length should be shorter than P6's foot length because P6 is taller (Metacognitive, Assessment of knowledge, Individual level, Realistic \& Language).

S65. P8: Then, the foot size 38 is $25 \mathrm{~cm}$. Then, how many $\mathrm{cm}$ is the foot size 36 (Metacognitive, New idea \& Assessment of strategy appropriateness, Environmental level, Realistic \& Language)?

Pre-service teachers both measure the foot length and height for themselves and other female pre-service teachers. They thought that the shoe length is not the same as foot length. They tried to check the mathematical model they have conducted via GeoGebra for people who have different height. They expressed that taller people's shoe length is bigger. They used their previous mathematical content knowledge.

S71. P8: Actually, measuring one male person's foot length makes more sense. In fact, we do not know if it (the footprint in the question) belongs to a male or not. It can belong to a female (Metacognitive, New idea \& Assessment of strategy appropriateness, Individual level, Language).

S72.P5: It can be very good to measure Amias's height. Can we reach a function with regression (Metacognitive, New idea \& Assessment of progress toward goal, Individual \& Social level, Realistic \& Pictorial)?

S76. P8: Are we going to generalize it? Can you look at the paper if there is a generalization (Metacognitive, Assessment of strategy appropriateness, Individual \& Social level, Realistic \& Symbolic)? 
S79. P8: First we should get foot length from foot size. Then, we should do the generalization. We should check the difference between foot size and foot length. Then, we should get the height (Metacognitive, New idea \& Assessment of understanding, Individual \& Social level, Language).

S80. P7: We should get the golden ratio form these data. How do we figure golden ratio in our body (Metacognitive, Assessment of strategy appropriateness, Individual level, Realistic \& Language)?

S83. P8: But someone's height and foot length can be disproportionate (Metacognitive, New idea \& Assessment of strategy appropriateness, Individual level, Language).

S85. P8: I wonder if there is golden ratio between height and foot length (Metacognitive, New idea \& Assessment of knowledge, Individual \& Social level, Realistic \& Language).

S93. P7: We should check if we can reach a function (Metacognitive, Assessment of progress toward goal, Individual \& Environmental level, Realistic \& Language).

S105. P7: First, let's divide foot size by foot length. It is one point something. We may reach golden ratio (Metacognitive, New idea \& Assessment of strategy appropriateness, Language \& Symbolic).

S108. P8: I do not think there is golden ratio between foot length and foot size (Data entry is completed.) (Metacognitive, Assessment of strategy appropriateness, Individual \& Social \& Environmental level, Language).

Pre-service teachers thought that the footprint could belong to either a male or a female. They tried to measure males' height and foot length as they did for females. They also tried to figure out to make a generalization or create a mathematical model showing a relationship of foot size, foot length and height. They tried to use the golden ratio whether it may help to reach a generalization. During this step, they questioned if the mathematical model they developed was working or not. This is a natural step of the modeling process.

S109. P8: Should this be a line graph (Metacognitive, Assessment of strategy execution, Individual \& Environmental level, Language \& Pictorial)?

S111. P8: Yes, let's make a line graph. If we did this in Excel, it would be better (Metacognitive, Assessment of strategy execution, Individual \& Environmental level, Language \& Pictorial).

S112. P6: But there are no such tools in Excel (Cognitive, Environmental level, Language \& Realistic).

S113. P8: Could you open Excel? The graph in Excel is better. The graph here is deviant (Cognitive, Environmental level, Realistic \& Language \& Pictorial).

S114. P7: But here the graph is on the function. (They are looking for the appropriate function in GeoGebra) (Cognitive, Individual \& Environmental level, Language \& Realistic).

S115. P7: It should be an increasing graph. It should be an exponential function because it is from the daily life (Metacognitive, Assessment of progress toward goal, Social \& Environmental level, Realistic \& Language).

S117. P5: This function is ok. But of course, there is some deviation (Metacognitive, Assessment of accuracy of result, Social \& Environmental level, Realistic \& Language).

S118. P6: But there might be measurement errors (Metacognitive, Assessment of accuracy of result, Social \& Environmental level, Language).

(Pre-service teachers decided that the mathematical modeling or function should be exponential.)

S119. P8: Let's save these solutions in GeoGebra then. Now, we will correlate foot length and height (Cognitive, Individual \& Environmental level, Language \& Pictorial).

S120. P7: Yes (Cognitive, Individual level, Language).

S121. P8: Then, we should reach height from foot size (Cognitive, Individual level, Language). 
S122. P7: But we have measured foot length (Metacognitive, Assessment of knowledge, Individual \& Social level, Language).

S123. P8: There is no point of finding foot size then (Metacognitive, Assessment of strategy appropriateness, Individual \& Social level, Language).

S124. P7: Then we can reach the foot size from the measurement we got. Binary (Cognitive, Individual \& Social level, Language).

S126. P7: Because we do not know the foot size. We can measure the footprint on the floor (Metacognitive, Assessment of progress toward goal, Individual \& Environmental level, Realistic \& Language).

S128. P7: First, it becomes exponential in GeoGebra. It means this one is an exponential as well (Metacognitive, Assessment of accuracy of result, Individual \& Environmental level, Language \& Pictorial).

(Pre-service teachers are trying to find the function).

S130. P7: Hold on. What did we do first (Cognitive, Individual level, Language)?

S131. P8: Correlate the foot size and foot length (Cognitive, Individual level, Language).

S132. P7: Which type of function did we use? Was it an exponential function (Cognitive, Individual level, Language)?

S133. P8: Yes, we used exponential function (Cognitive, Individual level, Language).

S134. P7: Then, what did we do (Cognitive, Individual level, Language)?

S135. P8: We correlated the foot length and height. This one is logarithmic (Metacognitive, Assessment of understanding, Individual \& Environmental level, Language \& Symbolic).

S136. P7: No, it is not exponential function (Metacognitive, Assessment of understanding, Individual \& Social level, Language \& Symbolic).

S137. P8: Ooh, yes. First, it was logarithmic, was not it? It turned to exponential function when we changed $\mathrm{x}$ and $\mathrm{y}$ (Metacognitive, Assessment of understanding, Individual \& Environmental level, Language \& Symbolic).

S138. P7: Was $\mathrm{x}$ for foot size here (Cognitive, Individual \& Environmental level, Language \& Symbolic)?

S139. P8: No, $\mathrm{x}$ is for foot length (Cognitive, Individual \& Environmental level, Language \& Symbolic).

S140. P6: Was not it the other way around (Cognitive, Individual \& Environmental level, Language \& Symbolic)?

S141. P8: No, we know that how many $\mathrm{cm}$ that is. We do not know the foot size. We should reach the foot size from $\mathrm{cm}$ (foot length) (Metacognitive, Assessment of strategy appropriateness, Individual level, Language \& Symbolic).

S142. P5: Now, we should correlate these two (She means the first and second steps in the report) (Metacognitive, Assessment of knowledge, Individual \& Environmental level, Language \& Symbolic).

S143. P7: Will we do multiple regression here? Are we doing triple regression (Cognitive, Environmental level, Language \& Symbolic)?

Pre-service teachers have entered all the data set they collected into the GeoGebra software. They tried to find the best mathematical modeling among the created graphs in GeoGebra. They thought that as the created graph 
in GeoGebra is more representative of the data, as the model is more possible to be correct. Pre-service teachers tried to correlate foot size, foot length, and height. They thought that the function that showed the correlation among these variables should be exponential because the variables were from the real-life. It can be said that this idea is not only form the graph drawing in GeoGebra but also from their previous mathematical knowledge. The used the relationship between logarithmic and exponential functions. This reveals that they used their mathematical content knowledge effectively. During these steps, pre-service teachers used metacognitive strategies mostly at the social and environmental levels. Although the nature of the problem causes environmental level, effective technology usage plays an important role for this level in metacognitive strategies. When the technology is used for the solution, there are more social and environmental levels having an interaction in between. Mathematical models created by using technology affected pre-service mathematics teachers' mathematical content knowledge to develop higher-order thinking, abstract knowledge and various mathematical representations such as symbolic and pictorial.

S144. P8: Do we really need to find the relationship between those two? For example, cannot students get in this way? They can get from foot length to foot size, from foot size to height (Metacognitive, Assessment of strategy appropriateness, Individual \& Environmental level, Language \& Symbolic).

S145. P7: Okay, but there is also that we need to develop a tool (Metacognitive, Assessment of progress toward goal, Individual level, Language).

S146. P5: Should we do that? We get from foot length to foot size, from foot size to height (Metacognitive, Assessment of strategy appropriateness, Individual level, Language).

S147. P8: Okay, we already did this (Cognitive, Individual level, Language).

S148. P5: We do not do this (Cognitive, Environmental level, Language).

S149. P8: Okay. I just said that (Cognitive, Individual level, Language).

S150. P6: Actually, we can directly get height because we already know the foot size. It makes sense (Metacognitive, Assessment of strategy appropriateness, Individual level, Language).

S151. P8: I just said that already (Cognitive, Individual level, Language).

S152. P6: Yes, I think that is true. We will get from foot size to foot length, from foot length to height (Cognitive, Social level, Language).

S153. P8: No, we will not be able to get from foot size to height, because we do not know the foot size. We should get from foot length to foot size, from foot size to height. In general, there is a relationship between foot size and height except for some people. There is always an exception (Metacognitive, Assessment of strategy appropriateness, Environmental level, Language).

S154. P7: But is it necessary (Cognitive, Social level, Language)

S155. P8: But it does not make sense to use it (foot length \& foot size) (Cognitive, Social level, Language).

S156. P7: Do you mean we should get foot size from this (Cognitive, Social level, Language)

S157. P8: I am saying that we should get height from foot size (Cognitive, Individual \& Social level, Language).

S158. P6: If foot length is known, we get foot size. We should find a relationship between foot size and height (Metacognitive, Assessment of progress toward goal, Individual \& Social level, Language).

S159. P8: I have already been saying that. We already get foot size from foot length. Then, we should get height from foot size (Cognitive, Individual \& Social level, Language).

S160. P6: Yes (Cognitive, Individual level, Language). 
S161. P5: What if we get height directly from foot length (Metacognitive, New idea \& Assessment of strategy appropriateness, Individual \& Social level, Language)?

S162. P8: That is possible (Cognitive, Individual level, Language).

S163. P7: We can use other ways to find proximity. We can compare (Metacognitive, New idea \& Assessment of progress toward goal, Individual \& Social level, Language).

S164. P8: Actually, it is like verification (Cognitive, Individual \& Social level, Language).

S165. P7: Let's look at the foot size and height then (Cognitive, Individual \& Social level, Language).

S166. P5: Okay. Let's save this too (Cognitive, Individual \& Environmental level, Language).

S167. P8: Do you know what? We will be looking at the three data set. We will be using the one which is the closest (Metacognitive, Assessment of strategy execution, Individual \& Environmental level, Language \& Symbolic\& Pictorial).

S168. P7: We will say that they are close to each other, and show that the result is correct and develop a tool (Metacognitive, Assessment of strategy execution, Social \& Environmental, Language).

S169. Lecturer: GeoGebra is also a tool.

S170. P7: Shall we collect new data (Metacognitive, Assessment of strategy execution, Individual \& Social level, Language)?

S171. P8: We do not need them. We can use the data we already have (Cognitive, Social level, Language).

S172. P7: We should look at the logarithm. This is the best one (Metacognitive, Assessment of accuracy of result, Individual \& Environmental level, Language \& Symbolic \& Pictorial).

S173. P8: We are trying to get a ratio by dividing height by foot length (Metacognitive, Assessment of strategy execution, Individual level, Language \& Symbolic).

S174. P7: Which number is close to these (Metacognitive, New idea \& Assessment of strategy execution, Individual \& Environmental level, Language \& Symbolic)?

S175. P5: We should add them together and divide by the number of people (Metacognitive, New idea \& Assessment of strategy execution, Individual \& Environmental level, Language \& Symbolic).

S176. P8: P7, I want to say something. When the ratios diverge from 6.5, how heights deviate (Metacognitive, Assessment of accuracy of result, Individual \& Environmental level, Language \& Symbolic)?

S177. P7: What? I did not get that (Cognitive, Social level, Language).

S178. P8: For example, 6.50 incline or decline, how many $\mathrm{cm}$ changes in height? We will not reach an absolute result; we will find an interval (Metacognitive, Assessment of accuracy of result, Individual \& Environmental level, Language \& Symbolic \& Pictorial).

S179. P5: Let's do what I said (Add the averages and divide by the number of people) (Metacognitive, Assessment of accuracy of result, Individual \& Environmental level, Language \& Symbolic).

S180. P7: The average is 6.57 (Cognitive, Individual \& Social level, Language \& Symbolic).

S181. P5: I think, logarithm is good. We found many results. Which one will we choose (Metacognitive, Assessment of strategy execution \&Assessment of accuracy of result, Individual \& Social level, Language \& Symbolic \& Pictorial)? 
S182. P6: We should decide what we will be using (Cognitive, Individual \& Environmental level, Language).

S183. P8: We will not reach an absolute result. We can use a height interval (Metacognitive, New idea \& Assessment of progress toward goal, Individual \& Social level, Language).

S184. P7: Girls, that much research is enough. Everyone is completing (Cognitive, Individual \& Environmental level, Language).

S186. P6: Do we really need to do this? (Metacognitive, Assessment of strategy appropriateness, Individual \& Social \& Environmental level, Language \& Symbolic).

S187. P5: We should write what we did. We should write down all the ways (Cognitive, Individual \& Environmental level, Language).

S188. P6: We should, we should write (Cognitive, Individual \& Environmental level, Language).

S189. P7: This is a simple solution. Do you know what this is? You saw on the road, then measure to say that the result is around this, I mean to analyze. I mean we should do this first. This should be the first step. This should be the first calculation like around that (Metacognitive, Assessment of strategy execution, Individual \& Social \& Environmental level, Language \& Symbolic).

S190. P6: Well, this gives roughly result (Metacognitive, Assessment of accuracy of result, Individual \& Environmental level, Language \& Symbolic).

S191. P5: Should we get from length to size (Cognitive, Individual level, Language)?

S192. P7: We get from foot length to foot size. But there is no need for this. We get from foot size to height (Metacognitive, Assessment of strategy execution, Individual \& Social level, Language \& Symbolic).

S193. P6: If we do the first and third step, we do not need this (foot length \& height). I mean, should we do two or more (Metacognitive, Assessment of strategy execution, Individual \& Social \& Environmental level, Language \& Symbolic)?

S194. P7: Did we get height from size (Cognitive, Individual \& Social level, Language).

S195. P6: I think, we should find the foot size (Metacognitive, New idea \& Assessment of strategy execution, Individual \& Social level, Language).

S196. P8: Okay, we get from foot length to foot size (Cognitive, Individual \& Social level, Language).

S197. P7: Yes, is not it from foot length to height (Metacognitive, Assessment of progress toward goal, Individual \& Social level, Language)?

S198. P5: Then, there is no need for OFMA number. Just one thing would be enough (Metacognitive, Assessment of strategy execution, Individual \& Social level, Language).

S199. P7: Let's look at the relation between foot length and foot size (third step) (Metacognitive, New idea, Individual \& Environmental level, Language \& Symbolic).

S200. P8: Yes, get foot size from foot length and height from foot size (Metacognitive, Assessment of strategy execution, Individual \& Social level, Language).

S201. P6: We should write all three on the report. We should write that we used third step as well (Cognitive, Individual \& Social level, Language \& Symbolic).

S202. P5: How should we write on the report why we found three ways (Cognitive, Individual \& Social level \& Environmental, Language \& Symbolic)? 
S203. P7: Because this is a real-world problem. We need several approximate results (Metacognitive, Assessment of accuracy of result \& Assessment of strategy appropriateness, Individual \& Environmental level, Language \& Symbolic).

In this part of discussion, pre-service teachers more frequently used metacognitive strategies. They have understood completely that they need to develop a mathematical model for model eliciting activity. Instead of trial and error, they developed strategies for the solution of the problem. Then, they investigated and queried whether these strategies were appropriate. They have more efficient interaction. There is less metacognitive thinking at the individual level (Statements 145, 146, 150, and 173). They have worked on the mathematical models in mostly agreed cases. They have evaluated the strategy or the solution individually. Therefore, there are not much new ideas in this part of the discussion.

Pre-service teachers also used metacognitive strategies in both individual and social levels (Statements 158, 170, 192, 195, 197, 198 and 200). Thus, pre-service used more than one metacognitive strategy at the same time (Statements 161, 163, 181, 183). They also used more than one representation for their explanations of the content knowledge (Statements 181 and 193). Social interaction and the feedback from others made the preservice teachers to create more new ideas. MEAs promote pre-service teachers to develop their ideas and models.

Pre-service teachers also showed metacognitive thinking at both individual and environmental levels (Statements 144, 167, 172, 174, 175, 176, 178, 179, 190, 199, and 203). At first, metacognitive strategies at the environmental level were used because of the nature of the problem. Then, pre-service teachers developed metacognitive strategies at the environmental level by using technology to control and evaluate the ways for the solution. Using technology made pre-service teachers' mathematical modelling process better and faster in terms of evaluation and analysis of their strategies. They also had opportunities to represent their mathematical content knowledge in various ways such as pictorial and symbolic forms for higher order thinking. All metacognition levels (individual, social, and environmental) existed rarely in pre-service teachers statements. However, the statements at all these levels showed higher order thinking, better questioning, and qualified consideration for metacognitive skills.

\section{Discussion}

As Joseph (2010) revealed that technology has a positive impact on students' learning and their process of problem solving. In this study, we have showed that technology can be a catalyzer for metacognitive thinking. In the groups, pre-service teachers used technology to solve the footprint problem. They had the opportunity to use their metacognition skills in the technology supported environment. As Gurbin (2015) also mentioned, there might be a reason that students can be motivated in a technology supported environment. The results we reached out in this study also similar to Gurbin (2015) and Azevedo's (2005) explanations regarding that technology adaptation is related to metacognition. Additionally, metacognition is also essential for technology usage taking a significant part of education today (Gurbin, 2015).

Through experiencing the footprint problem, pre-service mathematics teachers had opportunity to understand better how to prepare, work and engage similar integrated STEM modeling activity for middle and secondary school students. Stolmann et al. (2015) showed that there has been a similar development for pre-service mathematics teachers. In this study, pre-service mathematics teachers used their technological mathematical content knowledge (TPACK; Mishra \& Koehler, 2006) to solve the problem. They used their mathematical content knowledge to understand the information given in the MEA and to create multiple mathematical representations. They should know what mathematical representations mean and make transitions between these. They used their pedagogical knowledge to evaluate each other's knowledge for making a decision in groups' discussion to write a report. They knew how to use GeoGebra software program. They used GeoGebra to solve the problem and create multiple mathematical representations needed.

Anything that activates students thinking about their learning, review, reflection, discussion, questioning, thinking aloud, monitoring, and social interaction can develop their metacognitive thinking (Bryce \& Whitebread, 2012; Goos 2002; Gurbin, 2015; Kim et al., 2013). Therefore, the learning environments should include these kinds of opportunities to facilitate students' metacognitive development process. In this study, writing a report about their solution for the footprint problem caused pre-service teachers to apply these metacognitive components, such as review, thinking aloud, and monitoring. The environment is not sufficient itself to develop metacognition. As metacognition has an important role on effective learning (Gurbin, 2015), 
teachers should also have a facilitator role on students' leaning in order to develop their metacognitions skills as the instructor did in this study.

Social constructivism emphasizes that knowledge cannot be transferred from one specialist to learner, but rather actively constructed by the learner while solving meaningful problems. Integrated STEM education provides meaningful learning. The meaningful learning can be enhanced through social constructivism. For this reason, STEM integration should be coherent with the theory of social constructivism (Jonassen \& Rohrer-Murphy 1999; Moore \& Smith, 2014). Therefore, footprint problem was asked pre-service teachers in groups of four or five to discuss and develop their ideas for a solution. Pre-service teachers were engaged in social constructivist and metacognitive learning environment through integrated STEM modeling activity. This learning environment supported pre-service mathematics teachers and led them develop individually, socially and environmentally their cognitive and metacognitive skills integrated mathematical content knowledge. So, this study showed how to put together cognitive and metacognitive skills and mathematical representation knowledge with multiple levels. In this process technology played important role. With the help of technology, pre-service teachers showed all representational modes.

\section{Conclusion}

Pre-service teachers were able to find solutions for the footprint problem. Therefore, we can say that they were able to use their content knowledge of proportionality and linear function modeling. Pre-service teachers used different representations to find a solution for the given footprint problem as a modeling activity. They tended to use different representations other than the symbolic representations for their solution. The footprint problem itself and GeoGebra access might be a reason for the usage of different representations such as pictorial and concrete.

In this study, pre-service teachers' cognition and metacognition thinking for the footprint problem and their representations were analyzed based on using related two frameworks (Johnson \& Lesh, 2003; Kim et al.,2013). Therefore, this study reveals an important perspective how pre-service teachers use representations and cognitive-metacognitive level of thinking.

Modeling activities play a significant role to develop pre-service teachers higher order thinking and metacognitive thinking in a technology-based environment. Therefore, modelling activities should be given to a group in a technology-based environment to make the modelling process more efficient.

\section{Recommendations}

A similar study with a different environment such as using different software or another modelling activity can be conducted. Therefore, it can be possible to compare pre-service teachers' thinking and the representations they use with this study.

Additionally, it can be more useful to conduct a study investigating middle or high school teachers' modeling activities usage in their mathematics classes to get a better understating of how in-service teachers instruct these modeling activities and how students react and think for modeling process. Therefore, we can develop modeling process efficiently in teacher preparation programs to serve the purpose of metacognitive thinking.

\section{Acknowledgments or Notes}

The authors would like to acknowledge and thank pre-service mathematics teachers for their participation in the research

\section{Scientific Ethics Declaration}

The authors declare that the scientific ethical and legal responsibility of this article published in JESEH journal belongs to the authors. 


\section{References}

Ang, K. C. (2015). Mathematical modelling in Singapore schools: A framework for instruction. In N. H. Lee \& K. E. D. Ng (Eds.), Mathematical modelling: From theory to practice (pp. 57-72). Singapore: World Scientific.

Artzt, A. F., \& Armour-Thomas, E. (1992). Development of a cognitive-metacognitive framework for protocol analysis of mathematical problem solving in small groups. Cognition and instruction, 9(2), 137-175. https://doi.org/10.1207/s1532690xci0902_3

Azevedo, R. (2005). Computer environments as metacognitive tools for enhancing learning. Educational Psychologist, 40(4), 193-197.

Bal, A. P., \& Doğanay, A. (2014). Improving primary school prospective teachers' understanding of the mathematics modeling process. Educational Sciences: Theory \& Practice, 14(4), 1375-1384.

Bell, D. (2016). The reality of STEM education, design and technology teachers' perceptions: A phenomenographic study. International Journal of Technology and Design Education, 26, 61-79.

Biggs, J. (1987). The process of learning. Sydney: Prentice Hall.

Blum, W. (2011). Can modelling be taught and learnt? Some answers from empirical research. In G. Kaiser, W. Blum, R. Borromeo Ferri \& G. Stillman (Eds.), International perspectives on the teaching and learning of mathematical modelling, trends in teaching and learning of mathematical modelling (pp. 15-30). Dordrecht: Springer.

Blum, W., \& Ferri, R. B. (2009). Mathematical modelling: Can it be taught and learnt? Journal of Mathematical Modelling and Application, 1(1), 45-58.

Blum, W., \& Leiss, D. (2007). How do students and teachers deal with mathematical modelling problems? The example Sugaloaf und the DISUM project. In C. Haines, P. L. Galbraith, W. Blum \& S. Khan (Eds.), Mathematical modelling (ICTMA12) - Education, Engineering and Economics. Chichester: Horwood.

Borba, M. C., \& Villarreal, M. (2005). Humans-with-media and the reorganization of mathematical thinking. New York: Springer.

Brophy, S., Klein, S., Portsmore, M., \& Rogers, C. (2008). Advancing engineering education in P-12 classrooms. Journal of Engineering Education 97, 269-387.

Brown, A., \& De Loache, J. (1983). Metacognitive skills. In M. Donaldson, R. Grieve, \& C. Pratt (Eds.), Early childhood development and education (pp. 3-35). Oxford: Blackwell.

Bruner, J. S. (1964). The course of cognitive growth. American psychologist, 19(1), 1.

Bryce, D., \& Whitebread, D. (2012). The development of metacognitive skills: Evidence from observational analysis of young children's behavior during problem-solving. Metacognition Learning, 7, 197-217.

Butler Wolf, N. (2015). Modeling with mathematics: Authentic problem solving in middle school. Portsmouth, New Hampshire: Heinemann.

Cai, J., Cirillo, M., Pelesko, J. A., Ferri, R. B., Stillman, G., English, L. D., Wake, G., Kaiser, G., \& Kwon, O. (2014). Mathematical modeling in school education: Mathematical, cognitive, curricular, instructional, and teacher educational perspectives. Proceedings of the Joint Meeting of PME 38 and PME-NA 36 (pp. 145-172). Canada: PME-NA.

Cardelle-Elawar, M. (1992). Effects of teaching metacognitive skills to students with low mathematical ability. Teaching and Teacher Education, 8(2), 109-121.

Carlson, M., Larsen, S., \& Lesh, R. (2003). Integrating a models and modeling perspective with existing research and practice. In R. Lesh \& H. M. Doerr (Eds.), Beyond constructivism: Models and modeling perspectives on mathematics problem solving, learning, and teaching. Mahwah, NJ: Lawrence Erlbaum Associates, Inc.

Chan, E. C. M. (2008). Using model-eliciting activities for primary mathematics classrooms. The Mathematics Educator, 11(1), 47-66.

Clement, L. (2004). A model for understanding, using, and connecting representations. Teaching Children Mathematics, 11(2), 97-102.

Cramer, K. A. (2003). Using a translation model for curriculum development and classroom instruction. In R. Lesh \& H. Doerr (Eds.), Beyond constructivism (pp. 449-463). Mahwah, NJ: Lawrence Erlbaum Associates.

Cramer, K. A., Monson, D. S., Wyberg, T., Leavitt, S., \& Whitney, S. B. (2009). Models for initial decimal ideas. Teaching Children Mathematics, 16(2), 106-117.

De Corte, E., Greer, B., \& Verschaffel, L. (1996). Mathematics teaching and learning. In D. C. Berliner \& R. C. Calfee (Eds.), Handbook of educational psychology (pp. 491-549). New York, NY, US: Macmillan Library Reference Usa; London, England: Prentice Hall International.

Deniz, D., \& Akgün, L. (2014). Ortaöğretim öğrencilerinin matematiksel modelleme yönteminin sınıf içi uygulamalarına yönelik görüşleri. Trakya Üniversitesi Eğitim Fakültesi Dergisi, 4(1), 103-116. 
Dewaters, J., \& S. E. Powers. (2006). Improving science and energy literacy through project-based K-12 outreach efforts that use energy and environmental themes. Proceedings of the 113th annual ASEE conference \& exposition. Chicago, IL.

Diefes-Dux, H. A., Hjalmarson, M. A., Miller, T., \& Lesh, R. (2008). Model-eliciting for engineering education. In In J. S. Zawojewski, H. A. Diefes-Dux, \& K. J. Bowman (Eds.), Models and modeling in engineering education: Designing experiences for all students (pp. 17-35). The Netherlands: Sense Publishers.

Diefes-Dux, H. A., \& Imbrie, P. K. (2008). Modeling activities in a first-year engineering course. In J. S. Zawojewski, H. A. Diefes-Dux, \& K. J. Bowman (Eds.), Models and modeling in engineering education: Designing experiences for all students (pp. 55-92). The Netherlands: Sense Publishers.

Doerr, H. M. (2007). What knowledge do teachers need for teaching mathematics through applications and modeling? In W. Blum, P. L. Galbraith, H.-W. Henn, \& M. Niss (Eds.), Modelling and applications in mathematics education: The 14th ICMI Study (1st ed., pp. 69-78). New York: Springer.

Doruk, B. K. (2010). Matematiği günlük yaşama transfer etmede matematiksel modellemenin etkisi [Unpublished doctoral dissertation]. Hacettepe Üniversitesi, Ankara.

Driscoll, M. P. (2000). Psychology of learning for instruction (2nd ed.). Boston, MA: Allyn and Bacon.

Duffy, T., \& Cunningham, D. (1996). Constructivism: Implications for the design and delivery of instruction. Handbook of research for educational communications and technology, 170-198.

Dunlosky, J., \& Metcalfe, J. (2009). Metacognition. Thousand Oaks, CA: Sage Publications, Inc.

English, L. D., Fox, J. L., \& Watters, J. J. (2005) Problem posing and solving with mathematical modeling. Teaching Children Mathematics, 12(3), 156-163.

Erbaş, A. K., Kertil, M., Çetinkaya, B., Çakiroğlu, E., Alacaci, C., \& Baş, S. (2014). Mathematical modeling in mathematics education: Basic concepts and approaches. Educational Sciences: Theory \& Practice, $14(4), 1621-1627$.

Eric, C. C. M. (2010). Tracing primary 6 students' model development within the mathematical modeling process. Journal of Mathematical Modeling and Applications, 1, 40-57.

Ferguson, R. L. (2007). Constructivism and social constructivism. In G. M. Bodner \& M. Orgill (Eds.), Theoretical frameworks for research in chemistry/science education (pp. 28-49). Upper Saddle River, NJ: Prentice Hall.

Fox, J. (2006). A justification for mathematical modelling experiences in the preparatory classroom. In P. Grootenboer, R. Zevenbergen, \& M. Chinnappan (Eds.), Proceedings of the 29th annual conference of the mathematics education research group of Australasia (pp. 221-228). Canberra: MERGA.

Furner, J. M., \& Marinas, C. A. (2012). Connecting geometry, measurement, and algebra using GeoGebra for the elementary grades. Twenty-fourth annual international conference on technology in collegiate mathematics (pp. 63-72). Orlando, Florida: Pearson Education Inc.

Gagne, R. M., Medsker, K. L. (1996). The Conditions of learning: Training applications. Harcourt Brace College Publishers: Fort Worth.

Glancy, A. W., \& Moore, T. J. (2013). Theoretical foundations for effective STEM learning environments. Education working papers (1-1-2013), School of Engineering Education, Purdue University. Accessed on 10/04/2016. http://docs.lib.purdue.edu/enewp/1

Goldin, G. A. (2007). Aspects of affect and mathematical modeling processes. In R. A. Lesh, E. Hamilton, \& J. J. Kaput (Eds.) Foundations for the future in mathematics education (pp. 281-296). Mahwah: Erlbaum.

Goos, M. (1994). Metacognitive decision making and social interactions during paired problem solving. Mathematics Education Research Journal. 6(2), 144-165.

Goos, M. (2002). Understanding metacognitive failure. The Journal of Mathematical Behavior, 21(3), 283-302.

Goos, M., \& Galbraith, P. (1996). Do it this way! Metacognitive strategies in collaborative mathematical problem solving. Educational Studies in Mathematics, 30, 229-260.

Goos, M., Galbraith, P., \& Renshaw, P. (2002). Socially mediated metacognition: Creating collaborative zones of proximal development in small group problem solving. Educational Studies in Mathematics, 49(2), 193-223. https://doi.org/10.1023/A:1016209010120

Gould, H., \& Wasserman, N. (2014). Striking a balance: Student's tendencies to oversimplify or overcomplicate in mathematical modeling. Journal of Mathematics Education at Teachers College, 5(1), 27-34.

Gurbin, T. (2015). Metacognition and technology adoption: Exploring influences. Procedia - Social and Behavioral Sciences, 191, 1576-1582. https://doi.org//10.1016/ j.sbspro.2015.04.608

Haines, C., \& Crouch, R. (2007). Mathematical modeling and applications: Ability and competence frameworks. In W. Blum, P. L. Galbraith, H. Henn, \& M. Niss (Eds.), Modelling and applications in mathematics education: e 14th ICMI study (pp. 417-424). New York, NY: Springer.

Hıdıroğlu, Ç. N., \& Bukova-Güzel, E. (2014). Matematiksel modellemede GeoGebra kullanımı: Boy-ayak uzunluğu problemi. Pamukkale Üniversitesi, Eğitim Fakültesi Dergisi, 36(2), 29-44. 
Hıdıroğlu, Ç. N. \& Bukova Güzel, E. (2015). Teknoloji destekli ortamda matematiksel modellemede ortaya çıkan üst bilişsel yapılar. Turkish Journal of Computer and Mathematics Education, 6(2), 179-208.

Hıdıroğlu, Ç. N., \& Bukova-Güzel, E. (2016). Transitions between Cognitive and Metacognitive Activities in Mathematical Modelling Process within a Technology Enhanced Environment. Necatibey Faculty of Education Electronic Journal of Science \& Mathematics Education, 10(1), 313-350.

Hohenwarter, M., Hohenwarter, J., Kreis, Y., \& Lavicza, Z. (2008). Teaching and learning calculus with free dynamic mathematics software GeoGebra. Proceedings of the 11th international congress on mathematical education. Monterrey, Nuevo Leon, Mexico.

Jacobse, A. E., \& Harskamp, E. G. (2009). Student-controlled metacognitive training for solving word problems in primary school mathematics. Educational Research and Evaluation, 15(5), 447-463.

Jacobse, A. E., \& Harskamp, E. G. (2012). Towards efficient measurement of metacognition in mathematical problem solving. Metacognition and Learning, 7(2), 133-149.

Johnson, T., \& Lesh, R. (2003). A models and modeling perspective on technology-based representational media. Beyond constructivism: Models and modelling perspectives on mathematics problem solving, learning, and teaching, 265-278.

Jonassen, D. H., \& Rohrer-Murphy, L. (1999). Activity theory as a framework for designing constructivist learning environments. Educational Technology Research and Development, 47(1), 61-79.

Joseph, N. (2010). Metacognition needed: Teaching middle and high school students to develop strategic learning skills. Preventing School Failure. 54(2), 99-103.

Kaiser, G., Blum, W., Borromeo Ferri, R. \& Stillman, G. (Eds, 2011). Trends in Teaching and Learning of Mathematical Modelling (ICTMA 14). Dordrecht: Springer.

Kaiser, G. \& Schwarz, B. (2006). Mathematical modelling as bridge between school and university. ZDM, 38, 196-208.

Kaiser, G., \& Sriraman, B. (2006). A global survey of international perspectives on modelling in mathematics education. ZDM, 38(3), 302-310.

Kaput, J., Hegedus, S., \& Lesh, R. (2007). Technology becoming infrastructural in mathematics education. In R. A. Lesh, E. Hamilton \& J. Kaput (Eds.), Foundations for the future in mathematics education (pp. 173191). Mahwah, NJ: Lawrence Erlbaum.

Kertil, M., \& Gurel, C. (2016). Mathematical modeling: A bridge to STEM education. International Journal of Education in mathematics, science and Technology, 4(1), 44-55. https://doi.org/10.18404/ijemst.95761

Kim Y. R., Park, M. S., Moore, T. J., \& Varma, S. (2013). Multiple levels of metacognition and their elicitation through complex problem-solving tasks. The Journal of Mathematical Behavior, 32(3), 377-396. https://doi.org/10.1016/j.jmathb.2013.04.002.

Koellner-Clark, K., \& Lesh, R. (2003). Whodunit? Exploring proportional reasoning through the footprint problem. School Science and Mathematics, 103(2), 92-98. https://doi.org/10.1111/j.1949-8594.2003 .tb18224.x

Kramarski, B., Mevarech, Z. R., \& Arami, M. (2002). The effects of metacognitive instruction on solving mathematical authentic tasks. Educational Studies in Mathematics, 49(2), 225-250. https://doi.org/10.1023/A:1016282811724

Lamon, S. J. (2003). Modelling in elementary school: Helping young students to see the world mathematically. In Mathematical modelling (pp. 19-33). Woodhead Publishing.

Lapp, D. A., \& Cyrus, V. F. (2000). Using data-collection devices to enhance students' understanding. Mathematics Teacher, 93(6), 504-510.

Lehrer, R., \& Schauble, L. (2000). Developing model-based reasoning in mathematics and science. Journal of Applied Developmental Psychology, 21(1), 39-48. https://doi.org/10.1016/S0193-3973(99)00049-0

Lesh, R. (1979). Mathematical learning disabilities: Consideration for identification, diagnosis, and remediation. In R. Lesh, D. Mierkiewicz, \& M. G. Kantowski (Eds.), Applied mathematical problem solving (pp. 166-175). Columbus, OH: ERIC/SMEAC.

Lesh, R., Amit, M., \& Schorr, R. Y. (1997). Using 'real-life' problems to prompt students to construct conceptual models for statistical reasoning. In I. Gal, \& J. B. Garfield (Eds.), The assessment challenge in statistics education (pp. 65-84). Burke, VA: International Statistical Institute.

Lesh, R., Cramer, K., Doerr, H., Post, T., \& Zawojewski, J., (2003) Using a translation model for curriculum development and classroom instruction. In Lesh, R. \& Doerr, H. (Eds.) Beyond constructivism: Models and modeling perspectives on mathematics problem solving, learning, and teaching. Lawrence Erlbaum Associates, Mahwah, New Jersey.

Lesh, R., \& Doerr, H. M. (2003). In what ways does a models and modeling perspective move beyond constructivism? In R. Lesh \& H. M. Doerr (Eds.), Beyond constructivism: Models and modeling perspectives on mathematics teaching, learning, and problem solving. Mahwah, NJ: Lawrence Erlbaum Associates, Inc. 
Lesh, R., \& Fennewald, T. (2010). Introduction to part I modeling: What is it? Why do it? In R. Lesh, C. Haines, P. L. Galbraith, \& A. Hurford (Eds.), Modeling students' mathematical modeling competencies (pp. 5-10). New York: Springer.

Lesh, R., \& Harel, G. (2003). Problem solving modeling and local conceptual development. Mathematical Thinking and Learning 5(2-3), 157-189.

Lesh, R., Hoover, M., Hole, B., Kelly, A., \& Post, T. (2000). Principles for developing thought-revealing activities for students and teachers. In A. Kelly \& R. Lesh (Eds.), Research Design in mathematics and science education (pp. 591-646). New Jersey: Lawrence Erlbaum Associates, Inc.

Lesh, R., \& Lehrer, R. (2003). Models and modeling perspectives on the development of students and teachers. Mathematical Thinking and Learning, 5(2-3), 109-129.

Lesh, R., Post, T., \& Behr, M. (1987). Representation and translations among representations in mathematics learning and problem solving. In C. Janvier (Ed.), Problems of representation in the teaching and learning of mathematics (pp. 33-40). Hillsdale, NJ: Lawrence Erlbaum Associates.

Lesh, R., \& Yoon, C. (2007). What is distinctive in (our views about) models \& modelling perspectives on mathematics problem solving, learning, and teaching? In W. Blum, P. L. Galbraith, H. W. Henn, \& M. Niss (Eds.), Modelling and applications in mathematics education (pp. 161-170). New York: Springer.

Lesh, R., \& Zawojewski, J. S. (2007). Problem solving and modeling. In F. Lester (Ed.), The handbook of research on mathematics teaching and learning (2nd ed.) (pp. 763-804). Reston, VA/Charlotte, NC: National Council of Teachers of Mathematics.

Lester, F. K. (1994). Musings about mathematical problem-solving research: 1970-1994. Journal for Research in Mathematics Education, 25(6), 660-675.

Lester, F. K., Garofalo, J., \& Kroll, D. L. (1989). Self-confidence, interest, beliefs, and meta-cognition: Key influences on problem-solving behavior. In D. B. McLeod \& V. M. Adams (Eds.), Affect and mathematical problem solving (pp. 75-88). New York, NY: Springer-Verlag. https://doi.org/10.1007/978-1-4612-3614-6_6

Lester, F. K., \& Kehle, P. E. (2003). From problem solving to modeling: The evolution of thinking about research on complex mathematical activity. In R. Lesh \& H. M. Doerr (Eds.), Beyond constructivism: Models and modeling perspectives on mathematics teaching, learning, and problem solving. Mahwah, NJ: Lawrence Erlbaum Associates, Inc.

Lingefjärd, T. (2000). Mathematical modeling by prospective teachers using technology [Electronically published doctoral dissertation]. University of Georgia. http://ma-serv.did.gu.se/matematik/thomas.htm

Lingefjärd, T. (2007a). Mathematical modelling in teacher education- Necessity or unnecessarily. In W. Blum, P. L. Galbraith, H. W. Henn, \& M. Niss (Eds.), Modelling and applications in mathematics education: The 14th ICMI study (pp. 333-340). New York: Springer.

Lingefjärd, T. (2007b). Modelling in teacher education. In W. Blum, P. L. Galbraith, H. W. Henn, \& M. Niss (Eds.), Modelling and applications in mathematics education: The 14th ICMI study (pp. 475-482). New York: Springer.

Lowery, N. (2002). Construction of teacher knowledge in context: Preparing elementary teachers to teach mathematics and science. School Science and Mathematics, 102(2), 68-83.

Lucangeli, D., \& Cornoldi, C. (1997). Arithmetic education and learning in Italy. Journal of Learning Disabilities, 37(1), 42-49.

Maaß, K. (2007). Modelling in class: What do we want the students to learn. Mathematical modelling: Education, engineering and economics, 63-78.

Magiera, M. T., \& Zawojewski, J. (2011). Characterizations of social-based and self-based contexts associated with students' awareness, evaluation, and regulation of their thinking during small-group mathematical modelling. Journal for Research in Mathematics Education, 42(5), 486-520.

Mayer, R. E. (1998). Cognitive, metacognitive, and motivational aspects of problem solving. Instructional Science, 26(1-2), 49-63.

Mayer, R. E. (2003). Mathematical problem solving. In: J. M. Royer (Ed.), Mathematical cognition (pp. 69-92). Connecticut: Information Age Publishing.

Milanović, I., Vukobratović, R., \& Raičević, V. (2012). Mathematical modelling of the effect of temperature on the rate of a chemical reaction. Croatian Journal of Education, 14(3), 681-709.

Mishra, P., \& Koehler, M. J. (2006). Technological pedagogical content knowledge: A framework for teacher knowledge. Teachers college record, 108(6), 1017.

Montague, M., \& Bos, C. S. (1990). Cognitive and metacognitive characteristics of eighth grade students' mathematical problem solving. Learning and individual differences, 2(3), 371-388.

Moore, T. J., Miller, R. L., Lesh, R. A., Stohlmann, M. S., \& Kim, Y. R. (2013). Modeling in engineering: The role of representational fluency in students' conceptual understanding. Journal of English Education, 102, 141-178. https://doi.org/10.1002/jee.20004. 
Moore, T. J., \& Smith, K. A. (2014). Advancing the state of the art of STEM integration. Journal of STEM Education: Innovations and Research, 15(1), 5-10.

Morrison, J. (2006). Attributes of STEM education: The student, the school, the classroom. Baltimore, MD: The Teaching Institute for Excellence in STEM.

National Council of Teachers of Mathematics. (2000). Principles and standards for school mathematics. Reston, VA: NCTM.

Niss, M., Blum, W., \& Galbraith, P. (2007). Introduction. In W. Blum, P. L. Galbraith, H. W. Henn, \& M. Niss (Eds.), Modelling and applications in mathematics education: The 14th ICMI study (pp. 3-32). New York: Springer.

Nugent, G., Bradley, B., Grandgenett, N., \& Adamchuk, V. I. (2010). Impact of robotics and geospatial technology interventions on youth STEM learning and attitudes. Journal of Research on Technology in Education, 42(4), 391e408.

Özsoy, G., \& Ataman, A. (2009). The effect of metacognitive strategy training on mathematical problem solving achievement. International Electronic Journal of Elementary Education, 1(2), 67-82.

Pintrich, P. R., Anderman, E. M., \& Klobucer, C. (1994). Intraindividual differences in motivation and cognition in students with and without learning disabilities. Journal of Learning Disabilities, 27(6), 360-370.

Polya, G. (1957). How to solve it: A new aspect of mathematical method. $2 d$ Ed. Doubleday.

Post, T. R., Behr, M., \& Lesh, R. (1986). Research-based observations about children's learning of rational number concepts. Focus on Learning Problems in Mathematics, 8, 39-48.

Post, T. R., \& Cramer, K. (1989). Knowledge, representation, and qualitative thinking. In M. Reynolds (Ed.), Knowledge base for the beginning teacher-Special publication of the AACTE (pp. 221-231). Oxford: Pergamon Press.

Pugalee, D. K. (2001). Writing, mathematics, and metacognition: Looking for connections through students' work in mathematical problem solving. School Science and Mathematics, 101(5), 236-245. https://doi.org/10.1111/j.1949-8594.2001.tb18026.x

Revlin, R. (2013). Cognition: Theory and practice. New York: Worth Publishers.

Rodgers, K. J., Diefes-Dux, H. A., Kong, Y., \& Madhavan, K. (2015). Framework of basic interactions to computer simulations: Analysis of student developed interactive computer tools. Proceedings of the 122nd ASEE annual conference \& exposition: Making value for society, Seattle, WA.

Roehrig, G. H., Moore, T. J., Wang, H. H., \& Park, M. S. (2012). Is adding the E enough? Investigating the impact of K-12 engineering standards on the implementation of STEM integration. School Science and Mathematics, 112(1), 31-44.

Roth, W. M. (2007). Mathematical modeling 'in the wild': A case of hot cognition. In R. Lesh, J. J. Kaput, E. Hamilton, \& J. Zawojewski (Eds.), Users of mathematics: Foundations for the future. Mahwah, NJ: Lawrence Erlbaum Associates.

Rysz, T. (2004). Metacognition in learning elementary probability and statistics [Doctoral dissertation]. University of Cincinnati, Ohio.

Schoenfeld, A. H. (1992). Learning to think mathematically: Problem solving, metacognition and sense making in mathematics. In D. Grouws (Ed.), Handbook of research on mathematics teaching and learning (pp. 334-370). New York, NY: Macmillan.

Stacey, K. (1991). Making optimal use of mathematical knowledge. Australian Journal of Remedial Education, 22(4), 6-10.

Stillman, G. (2004). Strategies employed by upper secondary students for overcoming or exploiting conditions affecting accessibility of applications tasks. Mathematics Education Research Journal, 16(1), 41-71.

Stillman, G. (2011). Applying metacognitive knowledge and strategies in applications and modelling tasks at secondary school. In G. Kaiser, W. Blum, R. Borromeo Ferri, \& G. Stillman (Eds.), International perspectives on the teaching and learning of mathematical modelling, Trends in teaching and learning of mathematical modelling (pp. 165-180). Dordrecht: Springer.

Stillman, G., \& Galbraith, P. L. (1998). Applying mathematics with real world connections: Metacognitive characteristics of secondary students. Educational Studies in Mathematics, 36(2), 157-194.

Stillman, G., \& Mevarech, Z. (2010). Metacognition research in mathematics education: From hot topic to mature field. ZDM-International Journal on Mathematics Education, 42(2), 145-148.

Stohlmann, M. S., Maiorca, C., \& Olson, T. A. (2015). Preservice secondary teachers' conceptions from a mathematical modeling activity and connections to the common core state standards. Mathematics Educator, 24(1), 21-43.

Stohlmann, M. S., Moore, T. J., \& Cramer, K. (2013). Preservice elementary teachers' mathematical content knowledge from an integrated STEM modelling activity. Journal of Mathematical Modelling and Application, 1(8), 18-31. 
Tam, K. C. (2011). Modeling in the common core state standards. Journal of Mathematics Education at Teacher College, 2(1), 28-33.

Tan, L. S., \& Ang, K. C. (2013). Pre-service secondary school teachers' knowledge in mathematical modellingA case study. In Teaching Mathematical Modelling: Connecting to Research and Practice (pp. 373383). Netherlands: Springer.

Teague, D., Levy, R., \& Fowler, K. (2016). The GAIMME report: Mathematical modeling in the K-16 curriculum. In C. Hirsch (Ed.), Annual perspectives in mathematics education (APME): Mathematics modeling and modeling with mathematics (pp. 249-261). Reston, VA: National Council of Teachers of Mathematics.

Teong, S. K. (2003). The effect of metacognitive training on mathematical word-problem solving. Journal of Computer Assisted Learning, 19(1), 46-55.

Trainin, G., \& Swanson, H. L. (2005). Cognition, metacognition, and achievement of college students with learning disabilities. Learning Disability Quarterly, 28(4), 261-272 https://doi.org/10.2307/4126965

Vorhölter, K. (2018). Conceptualization and measuring of metacognitive modelling competencies: Empirical verification of theoretical assumptions. ZDM Mathematics Education, 50(1-2), 343-354. https://doi.org/10.1007/s11858-017-0909-x

Yimer, A., \& Ellerton, N. F. (2006). Cognitive and metacognitive aspects of mathematical problem solving: an emerging model. In P. Grootenboer, R. Zevenbergen, \& M. Chinnappan (Eds.), Identities, cultures, and learning spaces (pp. 575-582). Adelaide, Australia: Mathematics Education research Group of Australasia.

Yu, P. W. D., \& Tawfeeq, D. A. (2011). Can a kite be a triangle? Bidirectional discourse and student inquiry in a middle school interactive geometric lesson. New England Mathematics Journal, 43, 7-20.

Zawojewski, J. S., Diefes-Dux, H., \& Bowman, K. (2008). Models and modeling in engineering education. Sense Publishers.

\section{Mehmet Ali Kandemir}

Balıkesir University, Faculty of Education

Soma Yolu Cad. 10100 Altıeylül/ Balıkesir, TURKEY

Contact e-mail: kandemir@balikesir.edu.tr

ORCID-iD: 0000-0003-1598-5108

\section{Author Information}

\section{Ilyas Karadeniz}

Siirt University, Faculty of Education,

Siirt, TURKEY

ORCID-iD: 0000-0002-5470-2011

\section{Appendix A}

\section{The Footprint Problem}

Early this morning, Shirley Jones, the local police detective, discovered that sometime late last night some nice people rebuilt the old brick drinking fountain in the park. The mayor, Maria Lopez, would like to thank the people who did it, but nobody saw who it was. All the police could find were lots of footprints. One of the footprints is shown here. But to find this person and his or her friends, it would help it we could figure out how tall he or she really is. Your job is to make a "how to" tool kit that the police can use to figure out how tallpeople are just by looking at their footprints. Your tool kit should work for the footprint shown here, but it should also work for other footprints. 